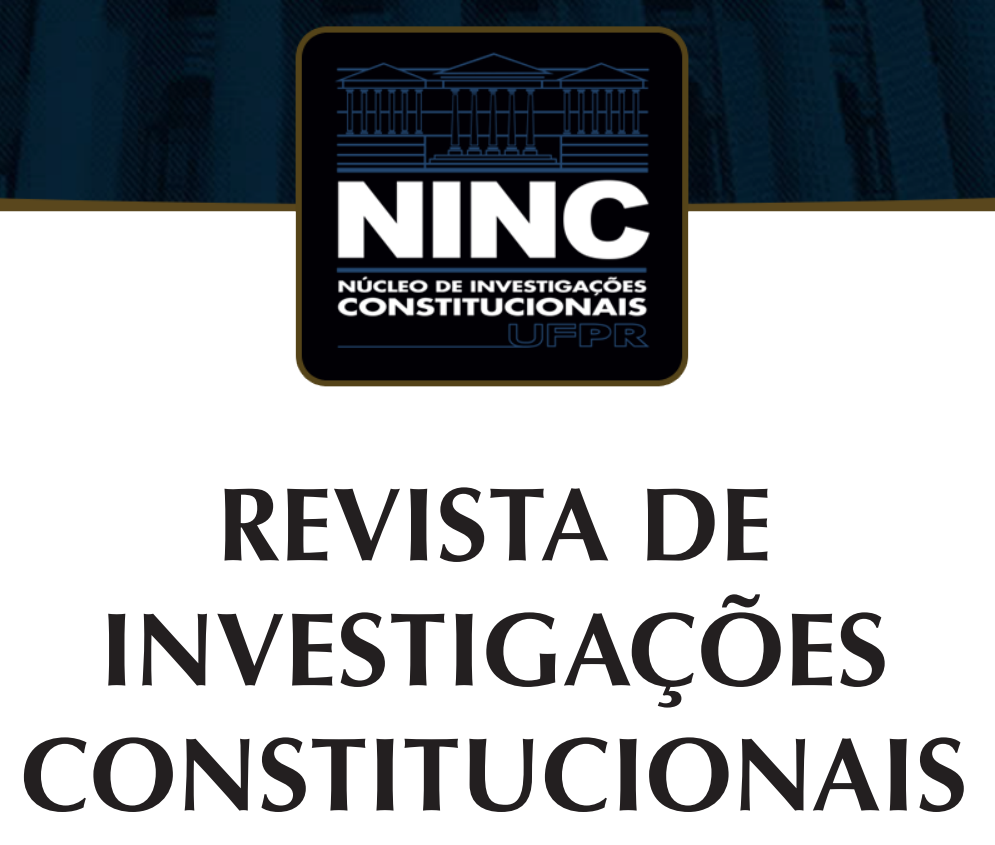

JOURNAL OF CONSTITUTIONAL RESEARCH

vol. 7 | n. 1 | janeiro/abril 2020 | ISSN 2359-5639 | Periodicidade quadrimestral Curitiba | Núcleo de Investigações Constitucionais da UFPR | www.ninc.com.br 


\title{
Intra-party democracy index: a measure model from Brazil
}

\section{Índice de democracia intrapartidária: um modelo de medição desde o Brasil}

\author{
ENEIDA DESIREE SALGADO 1 ,* \\ 'Universidade Federal do Paraná (Curitiba, Paraná, Brasil) \\ desisalg@gmail.com \\ https://orcid.org/0000-0003-0573-5033 \\ Recebido/Received: : 27.05.2020 / May $27^{\text {th }}, 2020$ \\ Aprovado/Approved: 16.08 .2020 / August $16^{\text {th }}, 2020$
}

\section{Abstract}

Political parties are, by constitutional force, essential to Brazilian democracy, and equally necessary for the composition and functioning of republican institutions. The 1988 Brazilian Constitution also determines, from a systemic reading, that political parties should be internally democratic. Thus, the present work seeks to develop an intra-party democracy index from the Brazilian experience, considering the fields of Political Science and Electoral Law. The methodology used consisted in the analysis of the statutes of the political parties registered in Brazil until 2018, based on a series of variables, developed from the constitutional and legal norms and principles applicable to the parties, by the reading of the
Resumo

Os partidos políticos são, por força constitucional, essenciais à democracia brasileira, sendo igualmente necessários para a composição e funcionamento das instituições republicanas. A Constituição de 1988 determina, a partir de leitura sistêmica, que os partidos políticos sejam internamente democráticos. O presente trabalho busca desenvolver um índice de democracia interna intrapartidário a partir da experiência brasileira, a partir dos campos da Ciência Política e do Direito Eleitoral. A metodologia utilizada consistiu na análise dos estatutos dos partidos políticos existentes no Brasil até 2018, a partir de uma série de variáveis, desenvolvidas a partir das normas e princípios constitucionais e legais aplicáveis aos partidos, examinadas a

Como citar esse artigo/How to cite this article: SALGADO, Eneida Desiree. Intra-party democracy index: a measure model from Brazil. Revista de Investigações Constitucionais, Curitiba, vol. 7, n. 1, p. 107-136, jan./abr. 2020. DOI: 10.5380/rinc.v7i1.74101.

" Professor of Constitutional Law and Electoral Law at the Federal University of Paraná (Curitiba-PR, Brazil). Eneida Desiree Salgado earned her Ph.D. in Public Law from the Federal University of Paraná; her thesis focused on demonstrating the constitutional foundations of Brazilian Election Law. Her Master Degree in the same University concentrated in the constituent process and the democratic project. Dr. Salgado worked on the Electoral Court from 1995 to 2008 and has been a Constitutional Law and Election Law Professor at the Federal University of Paraná since 2008. She performed postdoctorate research on the National Autonomous University of Mexico, working on electoral integrity and election authorities; another postdoctorate research was on Political Science Program on the Federal University of Paraná, creating an intraparty democracy index. She has writings about political reforms, access to information, transparency and social control, gender quotes, judicial activism, fundamental rights, constitutional amendments, democratic theory, political parties, and electoral systems. Dr. Salgado is currently Constitutional Law and Election Law Professor at the Federal University of Paraná, leader of the Constitutional Research Center and coordinator of Politics from/by/for Women Project. She is a Visiting Scholar at the Jack W. Peltason Center for the Study of Democracy (CSD) University of California, Irvine. E-mail: desisalg@gmail.com. 
specialized literature, which were translated into questions, whose respective answers were transformed into data, presented as tables, which present the degrees of internal democracy of the Brazilian political parties. The results obtained indicate a low level of internal democracy in the parties, with little use of democratic mechanisms for their organization and decision-making. The investigation demonstrated the need to extend the study to concrete party practices, as well as research on how to make the functioning of parties more plural, which was not the subject of the investigation. It is concluded that even after the Brazilian re-democratization, political parties use oligarchic practices, incompatible with the Brazilian Constitution and with the democratic principle itself.

Keywords: political parties; internal organization of political parties; Brazilian Electoral Law; statutes of political parties; intra-party democracy. partir da literatura especializada, traduzidas em perguntas, cujas respectivas respostas foram transformadas em dados, apresentados a partir de tabelas, as quais apresentam os graus de democracia interna dos partidos políticos brasileiros. Os resultados obtidos indicam um baixo nível de democracia interna nos partidos, com pouco uso de mecanismos democráticos para sua organização $e$ tomada de decisões. A investigação demonstrou a necessidade de extensão do estudo para as práticas partidárias concretas, bem como a pesquisa acerca de como tornar mais plural o funcionamento dos partidos, o que não foi objeto da investigação. Conclui-se que mesmo após a redemocratização brasileira os partidos políticos se utilizam de práticas oligárquicas, em descompasso com a constituição brasileira e com o próprio princípio democrático.

Palavras-chave: partidos políticos; organização interna de partidos políticos; sistema eleitoral brasileiro; estatutos de partidos políticos; democracia intrapartidária.

\section{CONTENTS}

1. Introduction: Partisan Democracy and democracy within parties; 2. The model for measuring intra-party democracy; 3. The degree of internal democracy of Brazilian political parties; 4 . Conclusion: the low degree of democracy in Brazilian parties; 5. References.

\section{INTRODUCTION: PARTISAN DEMOCRACY AND DEMOCRACY WITHIN PARTIES}

Democracy has not always been representative and representative democracy has not always been associated with political parties. After the spread of universal suffrage on the Western World, representation became an essential mechanism for managing the participation of individuals in the democratic politics. Although there is no ontological connection between the idea of democracy and the existence of political parties, the increasing professionalization of politics during the 20th century has been accompanied by a tendency to monopolize the presentation of candidates through political parties. As a result, the key to representation, a fundamental part of contemporary democracies, lies within the partisan dominion. The link between representation and partisan affiliation, which endured for more than half of the 20th century and was absolutely consistent with the prominence of partisan associations as promoters of political awareness and public debate, can still be observed today, despite the rivalry of social movements and the low ability of political parties to aggregate supporters and channel social interests.

In Brazil, political parties are favoured by the Constitution with a very particular legal regime. For instance, the Constitution indicates partisan affiliation as a condition 
of eligibility for running for office ${ }^{1}$ (art. 14, $\S 3$, item V). It also assures parties, through Chapter V of Title II (Fundamental Rights and Guarantees), complete autonomy to define their internal structure, organization, and functioning, which are regulated by the Law on Political Parties (9,096/1995). The imposition of partisan affiliation as a condition of eligibility, when combined with the legal determination that the candidate's registration can only be issued by presenting the party conference minutes where the candidate was chosen (Law No. 9,504/1997, art. 11, §1, item I) establishes a partisan monopoly on the presentation of candidatures.

Due to this total control of partisan associations over the alternatives presented to the electorate, there are those who claim the existence of a State of Parties, ${ }^{2}$ in which the functioning of political institutions is essentially connected to a partisan system. While this bears some truth in the Brazilian context, there are nevertheless power structures that function, at least normatively, independently of political parties, such as the Judiciary, the Prosecution Service of the Union, and the Courts of Accounts. Thus, one can speak more precisely of a State with Parties or, even more rigorously, of a Partisan Democracy, in which the institutions that demand direct democratic legitimation require political parties for their composition and functioning.

The Brazilian constitutional democracy is, without a doubt, a partisan democracy, by explicit decision of the constituent power. In the same way, a systematic reading of the Constitution makes it possible to recognise the obligation of political parties to function and be organised democratically. The stipulation for the preservation of the democratic regime indicated in the Article 17, combined with the application of the theory of horizontal effect of fundamental rights, ${ }^{3}$ establishes that the parties, in addition to being instruments for the implementation of formal democracy, must also be internally democratic.

Given Brazil's status as a partisan democracy, and given related constitutional commitments to the internal democratic functioning of political parties, it is critical to examine the extent to which Brazilian citizens have access to political candidates who emerge from democratically governed political parties.

\footnotetext{
There is a peculiarity regarding the military, since the Constitution grants them the right to run for elected office (art. 14, §8), but prohibits them from partisan affiliation (art. 142, §3, item V). In order to ensure the principle of the unity of the Constitution, the Superior Electoral Court's rule, in paragraph 1 of article 14 of Resolution No. 21.608/2004, established: “§ 1 The condition of eligibility relative to party affiliation indicated in article 14, $\S 3$, item V, of the Constitution of The Federative Republic, is not required of militaries on active service who intend to run for elective office, with the request for candidacy registration being enough, after previous designation in a party conference" (free translation).

2 GARCÍA-PELAYO, Manuel. El Estado de partidos. Madrid: Alianza Editorial, 1996 [1986].

3 SARLET, Ingo Wolfgang. A eficácia dos direitos fundamentais. Uma teoria geral dos direitos fundamentais na perspectiva constitucional. Porto Alegre: Livraria do Advogado, 2015.
} 
Literature on Law is not prolific in dealing with the issue of intra-party democracy, especially in Brazil. A book published in 1966 by Manoel Gonçalves Ferreira Filho ${ }^{4}$ deals with the theme, as does a recent dissertation by Raymundo Campos Neto. ${ }^{5}$ In a search conducted in April 2017 in the Virtual Library Network using the term "democracia interna" in the title and subject fields, twelve records were found: five were articles on trade unions, one on social movements, one on the Judiciary, one on theoretical models of analysis of internal democracy in formal organizations ${ }^{6}$, and four on political parties. Of the latter four, two examined foreign systems ${ }^{7}$ and two dealt with the Brazilian perspective ${ }^{8}$. In a second search using the terms "partidos políticos" and "democracia" in the title, thirty-one articles were uncovered: the four previously found, eight on foreign systems ${ }^{9}$, three newspaper articles dealing superficially with the subject ${ }^{10}$, one exploring the association between political parties and environmental law, and fourteen discussing the relationship between political parties and democracy (without

4 FERREIRA FILHO, Manoel Gonçalves. Os partidos políticos nas Constituições democráticas. Belo Horizonte: Revista Brasileira de Estudos Políticos, 1966.

5 CAMPOS NETO, Raymundo. A democracia interna nos partidos políticos brasileiros. Belo Horizonte: Editora D'Plácido, 2017.

6 Published in Revista de Administração Pública in 1971.

7 LOMBARDI, Giorgi. Corrientes y democracia interna de los partidos políticos. Revista de estudios políticos, n. 27, pp. 7-28, mayo/jun. 1982. GARCÍA ROCA, F. Javier; MURILLO DE LA CUEVA, Pablo Lucas. Democracia interna y control de los partidos politicos - cronica del encuentro italo-español de octubre de 1983. Revista de estudios políticos, n. 42, pp. 239-268, nov./dic. 1984.

8 SALGADO, Eneida Desiree; PÉREZ HUALDE, Alejandro. A democracia interna dos partidos políticos como premissa da autenticidade democrática. A \& C: Revista de Direito Administrativo \& Constitucional, v. 15, n. 60, pp. 63-83, abr./jun. 2015. CERQUEIRA, Marcelo. Partidos políticos : democracia interna e financiamento de campanha: a reforma política e o jardineiro infiel. Revista da Academia Brasileira de Direito Constitucional, v. 10 B, pp. 343-364, 2006. It should be noted that the former also works with the Argentinean reality.

9 AGUIAR, Joaquim. Democracia pluralista, partidos políticos e relação de representação. Análise Social: Revista do Instituto de Ciências Sociais, v. 24, n. 100, pp. 59-76 1988. ORTEGA, Marvin. Democracia y partidos politicos en Nicaragua. Pensamiento iberoamericano: revista de economia política, n. 14, pp. 231-237, jul./ dic. 1988. RODRIGUEZ ALVAREZ, Maria Pilar. El principio de democracia en la estructura y funcionamiento de los partidos políticos. Revista de la Facultad de Derecho de la Universidad de Madrid, n. 81, pp. 291-300, 1993. SENA, Jorge F. Malem. Financiación de partidos políticos, democracia y corrupción. Revista dos Mestrandos em Direito Econômico da UFBA, n. 6, pp. 377-417, jan./dez. 1998. HILLMAN, Richard S.; D'AGOSTINO, Thomas J. Partidos políticos, opinião pública e o futuro da democracia na Venezuela. Opinião pública, v. 6, n. 1, pp. 55-76, abr. 2000. CRUZ, Ilídio. O papel dos partidos políticos numa democracia multipartidária. Paraná Eleitoral, n. 40, p. 63-68, abr./jun. 2001. ALMAGRO CASTRO, David. Democracia y financiación de los partidos políticos en España. Revista Direito GV, v. 10, n. 2, pp. 535-558, jul./dez. 2014.

10 BICUDO, Hélio. A Democracia nos partidos políticos. O Estado de São Paulo, n. 36279, 15 fev. 1993. caderno Economia \& Negócios / coluna Espaço Aberto, p. 2. CENEVIVA, Walter. Mudanças na lei dos partidos políticos garantirão a democracia. Folha de S. Paulo, n. 23384, 11 abr. 1993. caderno Cotidiano / coluna Letras Jurídicas, pp. 4-2. DIRCEU, José. A democracia e os partidos políticos. O Estado de São Paulo, n. 36270, 6 fev. 1993. caderno Economia \& Negócios / coluna Espaço Aberto, p. 2. 
dealing with the issue of democracy in the internal functioning of parties) ${ }^{11}$. Only one article was dedicated to the internal democracy of political parties ${ }^{12}$.

Concurrently, searches with various terms were conducted in the Social Science Research Network to uncover articles outside of the legal discipline. The term "internal democracy" resulted in four articles, all dealing with different realities, whether in the state field in a broad sense ${ }^{13}$ or in relation to parliamentary functioning ${ }^{14}$, but none of them were about Brazil. In the search for the term "political parties", of the nineteen papers found, only three (all by the same author) focused on the internal democracy of political parties, although tangentially and drawing on an analysis of the Mexican system $^{15}$. By combining the terms "candidate selection" and "political parties", thirty papers

11 BORJA, Célio. Os Partidos políticos e a democracia brasileira. Segurança \& desenvolvimento, v. 21, n. 149, pp. 111-117, 1972. REALE, Miguel. Os partidos políticos e a democracia no ocidente e no Brasil. Segurança \& desenvolvimento, v. 30, n. 186, pp. 47-56, 1981. GRIMM, Dietter. Os partidos políticos como pressupostos ou ameaças para a democracia. Revista de direito constitucional e ciência política, v. 4, n. 6, pp. 85-100, jan./ jun. 1988. JUCA, Francisco Pedro. Democracia e partidos políticos. Revista do Centro de Ciências Jurídicas da Universidade Federal do Pará, v. 1, n. 1, pp. 109-139, 1988. CARVALHO, Carlos Eduardo Vieira de. Os Partidos políticos e a democracia. Revista de ciência política / Instituto de Direito Público e Ciência Política, v. 33, n. 2, pp. 11-25, fev./abr. 1990. COSTA, Alcir Molina de. Democracia e partidos políticos. Revista de Direito da Defensoria Pública, v. 10, n. 13, pp. 219-221, 1998. STOKES, Susan C. Son los partidos políticos el problema de la democracia en America Latina? Política y gobierno, v. 5, n. 1, pp. 13-46, jan./jun. 1998. TEODORO, Luiz Cláudio de Almeida. Partidos políticos e democracia no Brasil. Caderno de filosofia e ciências humanas, v. 6, n. 10, pp. 144-150, abr. 1998. MEZZAROBA, Orides. A democracia, os partidos políticos e o Estado. Seqüência: Revista do Curso de Pós-graduação em Direito da UFSC, v. 22, n. 43, p. 29-44, dez. 2001. MORAES, Filomeno; LIMA, Martonio Mont'Alverne Barreto. Partidos políticos, eleições e a justiça eleitoral na construção da democracia no Brasil. Revista Latino-Americana de Estudos Constitucionais, n. 3, pp. 291-313, jan./jun. 2004. BARREIRO NETO, Jaime. Os partidos políticos como elementos essenciais à democracia moderna. Semestre eleitoral, v. 12, $\mathrm{n}$. 1/2, pp. 9-44, jan./dez. 2008. CAMBI, Eduardo; OLIVEIRA, Priscila Sutil de. Crise da democracia representativa e revitalização dos partidos políticos no Brasil. Revista dos Tribunais, v. 103, n. 949, pp. 39-67, nov. 2014. KLEIN, Antonio Carlos. Os partidos políticos e o paradoxo da democracia representativa. Revista Latino-Americana de Estudos Constitucionais, n. 16, pp. 369-390, dez. 2014. MARANHÃO, Jarbas. Partidos políticos e democracia. Revista de Informação Legislativa, v. 51, n. 201, pp. 245-249, jan./mar. 2014. YURTSEVER, Leyla Viga. A crise da democracia representativa e os partidos políticos no Brasil. L \& C: Revista de Administração Pública e Política, v. 17, n. 194, pp. 10-19, ago. 2014.

12 TEIXEIRA, José Eleares Marques. Democracia nos partidos políticos. Boletim Científico da Escola Superior do Ministério Público da União, v. 2, n. 8, pp. 83-98, jul./set. 2003.

13 ARANA, Xabier; HOGG, Alison H. Drug Policy and the Ultima Ratio in a Social and Democratic State, Spain (January 15, 2013). Oñati Socio-Legal Series, Vol. 3, No. 1, 2013. ARENAS CATALÁN, Eduardo Salvador. Democracy as a Legitimizing Principle for the Current Chilean Constitution: External and Internal Perspectives (August 11, 2006). LALANDER, Rickard. Venezuela 2010-2011: Polarización Y Radicalización Del Proyecto Socialista (September 2, 2012). Revista de Ciencia Política Vol. 32, No.1, 2012.

14 GIL-LAFUENTE, Jaime; ROJAS-MORA, Julio; ACUNA-AGOST, Rodrigo. Y Ahora con Quién Tenemos Que Pactar? Modelo Matemático Para la Obtención de Coaliciones de Gobierno en una Democracia Parlamentaria (March 23, 2009). Proceedings of the XXIII Anual Congress of the AEDEM, 2009.

15 MARTÍN REYES, Javier. De jueces, militantes y dirigencias partidistas: un panorama cuantitativo del control jurisdiccional de los conflictos intrapartidistas en México - 1996-2006. Veredas, Xochimilco, v. 25, p. 177-208, 2012. https://ssrn.com/abstract=2341384; MARTÍN REYES, Javier. El tribunal de los militantes: el control judicial de los conflictos intrapartidistas en México. América Latina Hoy, Salamanca, v. 62, p. 131-153, 2012. https:// ssrn.com/abstract=2341351.; MARTíN REYES, Javier. Un garantismo en tension: la primera integración del TEPJF y el control jurisdiccional de la vida interna de los partidos políticos. Justicia Electoral, vol. 1, n. 10, p. 223-266, 2012. https://ssrn.com/abstract=2341379. 
appeared, of which nine were dedicated to the theme. Of these, one had already been located through another search, six presented local studies, including one focusing on Latin America ${ }^{16}$, one discussed the replacement of parliamentarians, and one examined candidate selection from a gendered perspective ${ }^{17}$.

Two specific studies were referenced in several of the aforementioned studies on the subject, and were indicated by experts as being important to our understanding of the intra-party democracy to date: "Measuring Intra-Party Democracy: A Guide for the Content Analysis of Party Statutes with Examples from Hungary, Slovakia and Romania", by Benjamin von dem Berge, Thomas Poguntke, Peter Obert and Diana Tipei ${ }^{18}$, and "An Intra-Party Democracy Index: Theory, Design and a Demonstration", by Gideon Rahat and Assaf Shapira ${ }^{19}$. Based on the extensive use of these studies, they are used in this article to elaborate the model for measuring the degree of internal democracy of Brazilian political parties.

The first model presents a set of categories for measuring intra-party democracy based on three axes: rights of affiliates, organizational structure, and decision-making process. The third axis (decision-making process) includes two sub-categories: programmatic issues, and recruitment ${ }^{20}$. The second model presents an index of intra-party democracy, which takes into account five dimensions: participation, representation, competition, responsiveness, and transparency. More broadly, the proposal of these authors is to analyse both the formal party rules and the actual behaviour of the parties. In their framework, the index score is calculated from questions established for each dimension, with weights assigned to each dimension by the authors. The dimensions have different weights in the final index: thirty points are given for participation, twenty points for each of representation and competition, and fifteen points for each of responsiveness and transparency. ${ }^{21}$

\footnotetext{
16 ARAGON, Fernando M. Candidate Nomination Procedures and Political Selection: Evidence from Latin American Parties (January 2009). LSE STICERD Research Paper No. EOPP003.

17 FORTIN-RITTBERGER, Jessica and RITTBERGER, Berthold. Nominating Women for EP Elections: Exploring the Role of Political Parties' Recruitment Procedures (2014). APSA 2014 Annual Meeting Paper.

18 BERGE, Benjamin von dem; POGUNTKE, Thomas; OBERT, Peter; TIPEI, Diana. Measuring Intra-Party Democracy: A Guide for the Content Analysis of Party Statutes with Examples from Hungary, Slovakia and Romania. SpringerBriefs in Political Science, 2013.

19 RAHAT, Gideon; SHAPIRA, Assaf. An Intra-Party Democracy Index: Theory, Design and a Demonstration. Parliamentary Affairs, p. 1-27, 2016.

20 BERGE, Benjamin von dem; POGUNTKE, Thomas; OBERT, Peter; TIPEI, Diana. Measuring Intra-Party Democracy: A Guide for the Content Analysis of Party Statutes with Examples from Hungary, Slovakia and Romania. SpringerBriefs in Political Science, 2013.

21 RAHAT, Gideon; SHAPIRA, Assaf. An Intra-Party Democracy Index: Theory, Design and a Demonstration. Parliamentary Affairs, p. 1-27, 2016.
} 
Although Robert Michels argues about the inevitability of a hierarchical and fundamentally undemocratic partisan organization, ${ }^{22}$ such conclusions are not be addressed here, nor are criticism on the permanent functioning ${ }^{23}$ or existence of political parties. ${ }^{24}$ Rather, this study is based on the adoption of the democratic regime by the 1987 constituents and the mandatory observance of the democratic principle by political parties. In other words, the starting point of this study is the need, derived from Brazil's constitutional command, for the democratic organization of political parties. As noted above, and building on the two aforementioned indices, this study, drawing on Political Science and Law, proposes an index for measuring intra-party democracy that is applicable to Brazilian political parties, based on the demand for democracy imposed by the Constitution and the Law on Political Parties.

\section{THE MODEL FOR MEASURING INTRA-PARTY DEMOCRACY}

In a Democratic State governed by the Rule of Law, it is presumed that the exercise of political power is legitimised by the democratically expressed consent of the governed citizens. In a representative democracy, the designation of candidates, who will be presented as alternatives by the political parties to the electorate, must take place in a democratic manner, as must the formation of the parties' political bodies and the development of their guidelines. However, these concerns are not part of the normative set of considerations related to Brazilian political parties: the Constitution limits itself to determining that the parties must preserve the democratic regime; the legislation on political parties does not go further.

Some of the authors who deal with the issue place great emphasis on the autonomy of the parties as a way of protecting fundamental rights, since partisan autonomy is provided through Article 17 of Title II of the Constitution (Fundamental Rights and Guarantees). However, other fundamental rights also guaranteed, such as the right of association and the right to present oneself as an alternative to the electorate, do not seem to be promoted and protected with the same determination. There is no doubt, however, that political parties must function democratically, at least from a legal perspective, in view of their role in democratic states. Perhaps, from other perspectives, efficiency could take the place of democracy for the evaluation of political parties. However, for they are subjected to the constitutional order, the democratic value is already determined.

\footnotetext{
22 MICHELS, Robert. Los partidos políticos. Un estudio sociológico de las tendencias oligárquicas de la democracia moderna. 2 vols. Buenos Aires: Amorrortu, 2008 [1962].

23 OSTROGORSKI, Moisei. La democracia y los partidos políticos. Madrid: Editorial Trotta, 2008 [1912].

24 WEIL, S. Sobre a supressão dos partidos políticos. São Paulo: Iluminuras, 2018 [1940].
} 
Since the Law on Political Parties does not provide a very detailed regulation of partisan processes, the construction of a model for measuring the degree of internal democracy cannot be based solely on the legislation. The proposal presented here seeks to combine the constitutional and legal design with the contributions of the literature, based on the contributions of Berge, Poguntke, Obert and Tipei ${ }^{25}$, and Rahat and Shapira. ${ }^{26}$ From the premise that democracy means participation and control, this study asserts that partisan processes should be considered democratic when they allow participation and control by the affiliates in two dimensions: organizational structure and decision-making process. The third aspect presented by Berge et alli, ${ }^{27}$ rights of affiliates, are incorporated in the construction of the two other dimensions through its subcategories - rights of affiliates in general and minority rights. In the two dimensions, the perspectives presented by Rahat and Shapira are also incorporated: (i) participation, (ii) representation, (iii) competition, (iv) responsiveness and (v) transparency. ${ }^{28}$ In all items, the assembly and plebiscitary aspects will be considered, as indicated by Poguntke, Scarrow and Webb. ${ }^{29}$

The construction of the model is based on the Brazilian reality that partisan politics are determined by the Constitution, and by the stipulations found on the Law on Political Parties. Drawing on these two instruments, in relation to the two dimensions indicated, the statutes of the 35 parties registered in 2018 were analysed based on the 31 variables of the model (which were transformed into yes-no questions) as shown in Tables 1 and 2.

In order to avoid ideological bias in the assessment of parties' statutes, each statute was examined by two more researchers ${ }^{30}$. In the first round of analysis, which served as a pre-test of the variables, 264 divergences were found in the 1085 responses, that is, there was a discrepancy of $24.33 \%$. In the evaluation of these divergences, it was observed that most of them derived from an equivocal interpretation of the question, for example, considering whether the requirement of support from a certain number

25 BERGE, Benjamin von dem; POGUNTKE, Thomas; OBERT, Peter; TIPEI, Diana. Measuring Intra-Party Democracy: A Guide for the Content Analysis of Party Statutes with Examples from Hungary, Slovakia and Romania. SpringerBriefs in Political Science, 2013.

26 RAHAT, Gideon; SHAPIRA, Assaf. An Intra-Party Democracy Index: Theory, Design and a Demonstration. Parliamentary Affairs, p. 1-27, 2016.

27 BERGE, Benjamin von dem; POGUNTKE, Thomas; OBERT, Peter; TIPEI, Diana. Measuring Intra-Party Democracy: A Guide for the Content Analysis of Party Statutes with Examples from Hungary, Slovakia and Romania. SpringerBriefs in Political Science, 2013.

28 RAHAT, Gideon; SHAPIRA, Assaf. An Intra-Party Democracy Index: Theory, Design and a Demonstration. Parliamentary Affairs, p. 1-27, 2016.

29 POGUNTKE, Thomas; SCARROW, Susan E.; WEBB, Paul D. Party rules, party resources and the politics of parliamentary democracies: How parties organize in the 21st century. Party Politics, 2016.

30 Scientific Initiation researchers: Anderson Kwan, Erick Nakamura, Gustavo Correa, Juliano Pietzack, Rafaela Chiarelo, Raul Nicolas, Rayssa Porto, and Wesley Bergonzine. 
of members to compose a slate would be an obstacle to the possibility of any affiliate presenting themselves as a candidate to the partisan bodies.

With the justifications of the variables, also presented in Tables 1 and 2, a new assessment of each party's statute was conducted, using all 31 variables in the proposed model. In this final round, eleven disagreements (1.35\%) remained. In these cases, the final responses were attributed according to the normative force of the stipulations. For example, the variable on the participation of minorities did not receive a positive response if a party's statute provided that the party would "emphasize the participation of young people and women in the electoral process," unless the statute also included a mandatory reserve of vacancies for specific historically excluded groups.

The model is composed of variables constructed from the literature, whether directly or indirectly, and also from the Brazilian Constitution. For example, the variable "form of election" is considered democratic when it incorporates proportional representation, based on the understanding of scholars about the advantages of adopting this principle for democracies (even though they have not dealt with its application to party structures) and also on the Brazilian constituent choice of proportional representation.

A value of 0 was given for each negative answer and a value of 1 was given for each affirmative answer. Each dimension and each indicator has a maximum value of 1 , as well as the intra-party democracy index (IDI), which is determined by the average of the scores of the indicators, considering that each indicator has a different number of variables. The closer to 0 , the less democratic the party is in general and also in each dimension and in each of the indicators. A party that met all of the democratic demands would achieve a score of 1 . 
TABLE 1. IDI ANALYTICAL MODEL: EXPLAINED VARIABLES, EMPIRICAL CONCEPTS AND SOURCES IN THE LITERATURE (ORGANIZATIONAL STRUCTURE)

\begin{tabular}{|c|c|c|c|c|}
\hline Indicator & Variable & What is measured & Justification & Sources \\
\hline \multirow{5}{*}{$\begin{array}{l}\text { 1. Composi- } \\
\text { tion of the } \\
\text { partisan } \\
\text { bodies }\end{array}$} & $\begin{array}{l}\text { 1.1. Form of } \\
\text { election }\end{array}$ & $\begin{array}{l}\text { Is there statutory } \\
\text { provision for the } \\
\text { participation of } \\
\text { minority slates in } \\
\text { the composition } \\
\text { of management } \\
\text { bodies, with the } \\
\text { adoption of a pro- } \\
\text { portional system? }\end{array}$ & $\begin{array}{l}\text { The adoption of } \\
\text { the proportional } \\
\text { principle for elec- } \\
\text { tions is more de- } \\
\text { mocratic than the } \\
\text { majority principle, } \\
\text { as it allows mino- } \\
\text { rity party currents } \\
\text { to participate in } \\
\text { decision-making }\end{array}$ & $\begin{array}{l}\text { Mill (1981 } \\
\text { [1861]); Alencar } \\
\text { (1991 [1868]); } \\
\text { Salgado (2015); } \\
\text { Nunes (2015); } \\
\text { Coller and Corde- } \\
\text { ro (2018). }\end{array}$ \\
\hline & $\begin{array}{l}\text { 1.2. Requi- } \\
\text { rements for } \\
\text { candidacy }\end{array}$ & $\begin{array}{l}\text { Is there a statutory } \\
\text { provision for the } \\
\text { possibility of any } \\
\text { affiliate presenting } \\
\text { herself as a candi- } \\
\text { date for internal } \\
\text { bodies (with the } \\
\text { exception of the } \\
\text { requirement of } \\
\text { compliance with } \\
\text { financial obliga- } \\
\text { tions)? }\end{array}$ & $\begin{array}{l}\text { Broad access to } \\
\text { party positions, } \\
\text { without the need } \\
\text { for extended time } \\
\text { for party affiliation } \\
\text { or support, is more } \\
\text { democratic in view } \\
\text { of the potential } \\
\text { universality of pas- } \\
\text { sive suffrage. }\end{array}$ & $\begin{array}{l}\text { Gallo (2005); } \\
\text { Berge, Poguntke, } \\
\text { Obert and Tipei } \\
\text { (2013); Coller and } \\
\text { Cordero (2018) }\end{array}$ \\
\hline & $\begin{array}{l}\text { 1.3. Minority } \\
\text { rights }\end{array}$ & $\begin{array}{l}\text { Is there provision } \\
\text { for the necessary } \\
\text { participation of } \\
\text { minorities (wo- } \\
\text { men, blacks, young } \\
\text { people, indige- } \\
\text { nous people) in } \\
\text { the composition of } \\
\text { partisan bodies? }\end{array}$ & $\begin{array}{l}\text { The introduction } \\
\text { of historically and } \\
\text { culturally subal- } \\
\text { tern groups into } \\
\text { partisan bodies } \\
\text { through an ex- } \\
\text { press and effective } \\
\text { choice of statutes } \\
\text { composes a plura- } \\
\text { listic characteriza- } \\
\text { tion of democracy }\end{array}$ & $\begin{array}{l}\text { Berge, Poguntke, } \\
\text { Obert and Tipei } \\
\text { (2013); Coller and } \\
\text { Cordero (2018) }\end{array}$ \\
\hline & $\begin{array}{l}\text { 1.4. Term of } \\
\text { office }\end{array}$ & $\begin{array}{l}\text { Is the term of office } \\
\text { of managers defi- } \\
\text { ned in the bylaws } \\
\text { as four years or } \\
\text { less? }\end{array}$ & $\begin{array}{l}\text { The term of office } \\
\text { of up to } 4 \text { years is } \\
\text { considered demo- } \\
\text { cratic by analogy } \\
\text { with the Brazilian } \\
\text { constituent option } \\
\text { for this period }\end{array}$ & \\
\hline & $\begin{array}{l}\text { 1.5. Possibility } \\
\text { of re-election }\end{array}$ & $\begin{array}{l}\text { Is there a statutory } \\
\text { ban on re-election } \\
\text { of officers? }\end{array}$ & $\begin{array}{l}\text { Re-election slows } \\
\text { down the alterna- } \\
\text { tion of power, an } \\
\text { essential element } \\
\text { of democracy }\end{array}$ & \\
\hline
\end{tabular}




\begin{tabular}{|c|c|c|c|c|}
\hline & $\begin{array}{l}\text { 1.6. Possibility } \\
\text { of interrup- } \\
\text { tion of } \\
\text { term of office }\end{array}$ & $\begin{array}{l}\text { Is there a statutory } \\
\text { provision for remo- } \\
\text { ving officers from } \\
\text { office before the } \\
\text { end of their term } \\
\text { of office? }\end{array}$ & $\begin{array}{l}\text { The provision } \\
\text { for cases of dis- } \\
\text { missal of officers } \\
\text { before the end of } \\
\text { the term of office } \\
\text { prevents the pos- } \\
\text { sibility of abusive } \\
\text { exercise of power } \\
\text { by the officers. }\end{array}$ & $\begin{array}{l}\text { Berge, Poguntke, } \\
\text { Obert and Tipei } \\
\text { (2013) }\end{array}$ \\
\hline & $\begin{array}{l}\text { 1.7. Accoun- } \\
\text { tability to } \\
\text { affiliates }\end{array}$ & $\begin{array}{l}\text { Do officers have a } \\
\text { statutory duty to } \\
\text { publicly present } \\
\text { to members the } \\
\text { accounts of their } \\
\text { management and } \\
\text { the activities per- } \\
\text { formed? }\end{array}$ & $\begin{array}{l}\text { Transparency in } \\
\text { the exercise of } \\
\text { party mandates } \\
\text { enables control by } \\
\text { affiliates and pro- } \\
\text { motes democracy } \\
\text { within parties. }\end{array}$ & $\begin{array}{l}\text { Berge, Poguntke, } \\
\text { Obert and Tipei } \\
\text { (2013) }\end{array}$ \\
\hline \multirow{3}{*}{$\begin{array}{l}\text { 2. Conflict } \\
\text { resolution } \\
\text { system }\end{array}$} & $\begin{array}{l}\text { 2.1. Composi- } \\
\text { tion of the } \\
\text { responsible } \\
\text { body }\end{array}$ & $\begin{array}{l}\text { Is the body respon- } \\
\text { sible for conflict } \\
\text { resolution elected } \\
\text { by the members } \\
\text { and inclusive of } \\
\text { representatives of } \\
\text { minorities? }\end{array}$ & $\begin{array}{l}\text { The choice of } \\
\text { affiliates for the } \\
\text { members of the } \\
\text { body responsible } \\
\text { for conflict reso- } \\
\text { lution prevents } \\
\text { their training in } \\
\text { the interests of } \\
\text { the leaders and } \\
\text { the integration of } \\
\text { representatives of } \\
\text { minorities implies } \\
\text { greater plurality in } \\
\text { decisions. }\end{array}$ & $\begin{array}{l}\text { Berge, Poguntke, } \\
\text { Obert and Tipei } \\
\text { (2013) }\end{array}$ \\
\hline & $\begin{array}{l}\text { 2.2. Existence } \\
\text { of procedural } \\
\text { rules }\end{array}$ & $\begin{array}{l}\text { Does the statute } \\
\text { clearly provide for } \\
\text { the procedure for } \\
\text { the resolution of } \\
\text { conflicts between } \\
\text { bodies? }\end{array}$ & $\begin{array}{l}\text { The express pro- } \\
\text { vision of dispute } \\
\text { resolution proce- } \\
\text { dures allows the } \\
\text { parties to know in } \\
\text { advance how they } \\
\text { will be resolved } \\
\text { and can trigger } \\
\text { the statute in case } \\
\text { of noncompliance, } \\
\text { which avoids the } \\
\text { misuse of power } \\
\text { by the members of } \\
\text { the body. }\end{array}$ & \\
\hline & $\begin{array}{l}\text { 2.3. Guarantee } \\
\text { of adversarial } \\
\text { proceedings }\end{array}$ & $\begin{array}{l}\text { Is there a statutory } \\
\text { provision for the } \\
\text { contradictory? }\end{array}$ & $\begin{array}{l}\text { The contradictory } \\
\text { and the broad } \\
\text { defence are in- } \\
\text { dispensable ele- } \\
\text { ments for the } \\
\text { configuration of a } \\
\text { democratic proce- } \\
\text { dure. }\end{array}$ & Gresta (2014) \\
\hline
\end{tabular}




\begin{tabular}{|c|c|c|c|}
\hline $\begin{array}{l}\text { 2.4. Com- } \\
\text { position of } \\
\text { disciplinary } \\
\text { bodies }\end{array}$ & $\begin{array}{l}\text { Is the body respon- } \\
\text { sible for investiga- } \\
\text { ting disciplinary } \\
\text { shortcomings elec- } \\
\text { ted and composed } \\
\text { with the partici- } \\
\text { pation of minority } \\
\text { representatives? }\end{array}$ & $\begin{array}{l}\text { The choice of affi- } \\
\text { liates for members } \\
\text { of the body res- } \\
\text { ponsible for the } \\
\text { determination of } \\
\text { disciplinary faults } \\
\text { reflects participa- } \\
\text { tion and control. }\end{array}$ & $\begin{array}{l}\text { Berge, Poguntke, } \\
\text { Obert and Tipei } \\
\text { (2013) }\end{array}$ \\
\hline $\begin{array}{l}\text { 2.5. Func- } \\
\text { tioning of } \\
\text { disciplinary } \\
\text { bodies }\end{array}$ & $\begin{array}{l}\text { Is the body res- } \\
\text { ponsible for inves- } \\
\text { tigating discipli- } \\
\text { nary deficiencies } \\
\text { permanent and } \\
\text { are its procedures } \\
\text { provided for in the } \\
\text { statute? }\end{array}$ & $\begin{array}{l}\text { The permanent } \\
\text { nature of the body } \\
\text { responsible for the } \\
\text { investigation of } \\
\text { disciplinary defi- } \\
\text { ciencies prevents } \\
\text { its formation in } \\
\text { accordance with } \\
\text { the interest of the } \\
\text { leaders and the } \\
\text { provision of the } \\
\text { procedures gua- } \\
\text { rantees the possi- } \\
\text { bility of activating } \\
\text { the statute in case } \\
\text { of lack of effective- } \\
\text { ness of the rights } \\
\text { of defense. }\end{array}$ & \\
\hline $\begin{array}{l}\text { 2.6. Classifica- } \\
\text { tion of pu- } \\
\text { nishments }\end{array}$ & $\begin{array}{l}\text { Are disciplinary } \\
\text { faults and their } \\
\text { punishments pro- } \\
\text { vided for in the } \\
\text { statute? }\end{array}$ & $\begin{array}{l}\text { Given the impact } \\
\text { of fundamental } \\
\text { rights on private } \\
\text { relations and the } \\
\text { political parties' } \\
\text { monopoly on the } \\
\text { submission of } \\
\text { candidacies, the } \\
\text { existence of puni- } \\
\text { shments without } \\
\text { strictly definition } \\
\text { is not democratic. }\end{array}$ & \\
\hline $\begin{array}{l}\text { 2.7. Com- } \\
\text { prehensive } \\
\text { defense gua- } \\
\text { ranteed }\end{array}$ & $\begin{array}{l}\text { Do members sub- } \\
\text { jected to discipli- } \\
\text { nary proceedings } \\
\text { have adequate } \\
\text { time (3 days or } \\
\text { more) to present } \\
\text { their defence? }\end{array}$ & $\begin{array}{l}\text { The period of } \\
\text { three days for the } \\
\text { defense derives } \\
\text { from the usual pe- } \\
\text { riod for electoral } \\
\text { appeals provided } \\
\text { for in the Electoral } \\
\text { Code (art. 258). }\end{array}$ & \\
\hline
\end{tabular}




\begin{tabular}{|c|c|c|c|c|}
\hline & $\begin{array}{l}\text { 2.8. Possibility } \\
\text { of appeals }\end{array}$ & $\begin{array}{l}\text { Can sanctioned } \\
\text { members lodge } \\
\text { appeals against } \\
\text { their conviction? }\end{array}$ & $\begin{array}{l}\text { The possibility of } \\
\text { giving reasons for } \\
\text { non-conformity } \\
\text { with the decision } \\
\text { given and the } \\
\text { right to receive } \\
\text { a further assess- } \\
\text { ment of the case } \\
\text { are components } \\
\text { of democratic pro- } \\
\text { cesses. }\end{array}$ & $\begin{array}{l}\text { Berge, Poguntke, } \\
\text { Obert and Tipei } \\
\text { (2013) }\end{array}$ \\
\hline & $\begin{array}{l}\text { 2.9. Publicity } \\
\text { of resolutions }\end{array}$ & $\begin{array}{l}\text { Are the decisions } \\
\text { of conflict resolu- } \\
\text { tions and punish- } \\
\text { ments public? }\end{array}$ & $\begin{array}{l}\text { Publicising deci- } \\
\text { sions on conflicts } \\
\text { and punishments } \\
\text { allows affiliates } \\
\text { and society to con- } \\
\text { trol the conten- } \\
\text { tious procedures } \\
\text { of political parties. }\end{array}$ & $\begin{array}{l}\text { Berge, Poguntke, } \\
\text { Obert and Tipei } \\
\text { (2013) }\end{array}$ \\
\hline & $\begin{array}{l}\text { 3.1. Decentra- } \\
\text { lization } \\
\text { of the party }\end{array}$ & $\begin{array}{l}\text { Do partisan state } \\
\text { and local agencies } \\
\text { have decision- } \\
\text {-making power } \\
\text { over coalitions, dis- } \\
\text { tribution of resour- } \\
\text { ces, and selection } \\
\text { of candidates? }\end{array}$ & $\begin{array}{l}\text { The decentraliza- } \\
\text { tion of decisions } \\
\text { - despite the na- } \\
\text { tional character } \\
\text { of political parties } \\
\text { determined by the } \\
\text { Constitution - co- } \\
\text { rresponds to a de- } \\
\text { mocratic ideal of } \\
\text { participation and } \\
\text { control. }\end{array}$ & $\begin{array}{l}\text { Berge, Poguntke, } \\
\text { Obert and Tipei } \\
\text { (2013): Coller and } \\
\text { Cordero (2018) }\end{array}$ \\
\hline $\begin{array}{l}\text { 3. Relations- } \\
\text { hip be- } \\
\text { tween the } \\
\text { partisan } \\
\text { bodies }\end{array}$ & $\begin{array}{l}\text { 3.2. Decentra- } \\
\text { lisation } \\
\text { of resources }\end{array}$ & $\begin{array}{l}\text { Is there provision } \\
\text { for the allocation } \\
\text { of public resources } \\
\text { to state and local } \\
\text { bodies? }\end{array}$ & $\begin{array}{l}\text { The existence of } \\
\text { resources gua- } \\
\text { ranteed to local } \\
\text { bodies preserves } \\
\text { their capacity for } \\
\text { action and makes } \\
\text { the decentrali- } \\
\text { zation of power } \\
\text { more effective. }\end{array}$ & \\
\hline & $\begin{array}{l}\text { 3.3. Overco- } \\
\text { ming local } \\
\text { decisions }\end{array}$ & $\begin{array}{l}\text { Are there express } \\
\text { statutory provi- } \\
\text { sions for the repla- } \\
\text { cement or removal } \\
\text { of decisions taken } \\
\text { by local bodies by } \\
\text { national bodies? }\end{array}$ & $\begin{array}{l}\text { The faculty for lo- } \\
\text { cal authorities to } \\
\text { take decisions is } \\
\text { enhanced by ex- } \\
\text { pressly providing } \\
\text { the possibility of } \\
\text { overlapping a lo- } \\
\text { cal decision by a } \\
\text { resolution of the } \\
\text { national body. }\end{array}$ & $\begin{array}{l}\text { Berge, Poguntke, } \\
\text { Obert and Tipei } \\
\text { (2013) }\end{array}$ \\
\hline
\end{tabular}




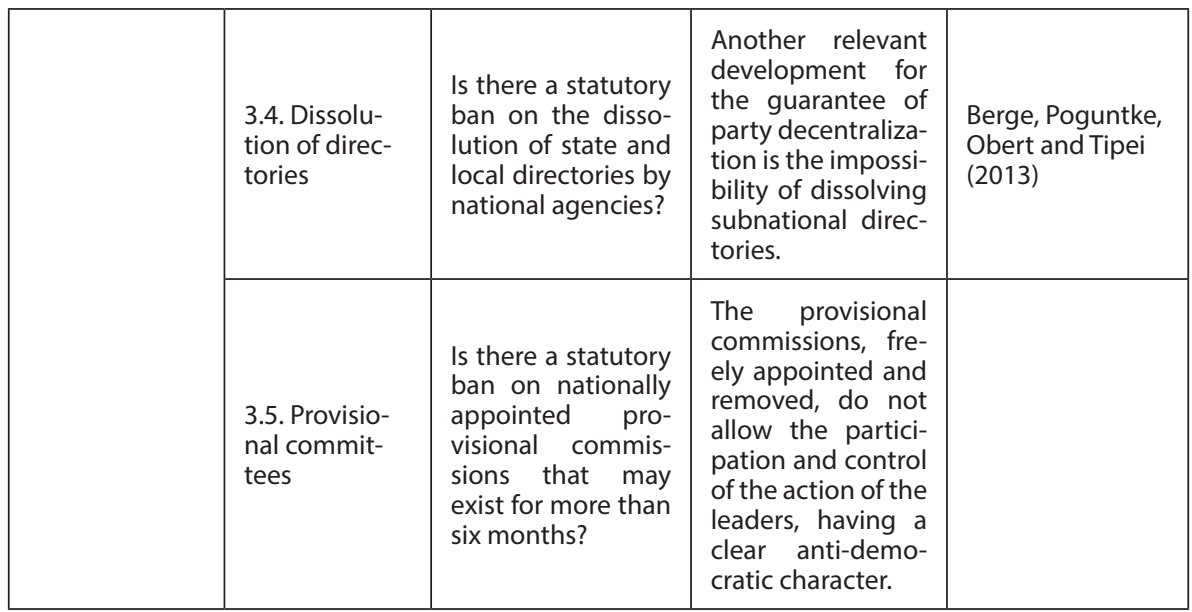

TABLE 2. IDI ANALYTICAL MODEL: EXPLAINED VARIABLES, EMPIRICAL CONCEPTS AND SOURCES IN THE LITERATURE (DECISION-MAKING PROCESS)

\begin{tabular}{|c|c|c|c|c|}
\hline Indicator & Variable & $\begin{array}{l}\text { What is measured } \\
\text { you }\end{array}$ & Justification & Sources \\
\hline \multirow{2}{*}{$\begin{array}{l}\text { 4. Definition } \\
\text { of the } \\
\text { program }\end{array}$} & $\begin{array}{l}\text { 4.1. Decen- } \\
\text { tralization in } \\
\text { the definition } \\
\text { of the party } \\
\text { program }\end{array}$ & $\begin{array}{l}\text { Is there a statutory } \\
\text { requirement for } \\
\text { the participation of } \\
\text { state and munici- } \\
\text { pal agencies in the } \\
\text { preparation and } \\
\text { reform of the party } \\
\text { program? }\end{array}$ & $\begin{array}{l}\text { The participation } \\
\text { of local bodies } \\
\text { in redefining the } \\
\text { organisation and } \\
\text { functioning of the } \\
\text { party is a measure } \\
\text { of party decentra- } \\
\text { lisation, one of the } \\
\text { facets of internal } \\
\text { democracy. }\end{array}$ & $\begin{array}{l}\text { Berge, Pogun- } \\
\text { tke, Obert and } \\
\text { Tipei (2013) }\end{array}$ \\
\hline & $\begin{array}{l}\text { 4.2. Inclusion } \\
\text { in the defi- } \\
\text { nition of the } \\
\text { party program }\end{array}$ & $\begin{array}{l}\text { Is there a statutory } \\
\text { provision for the } \\
\text { participation of af- } \\
\text { filiates in the elabo- } \\
\text { ration and reform of } \\
\text { the party program? }\end{array}$ & $\begin{array}{l}\text { The permeability of } \\
\text { the process of draf- } \\
\text { ting and reforming } \\
\text { the statute through } \\
\text { the participation of } \\
\text { affiliates is directly } \\
\text { related to the de- } \\
\text { mand for partici- } \\
\text { pation and control } \\
\text { that make up the } \\
\text { notion of demo- } \\
\text { cracy. }\end{array}$ & $\begin{array}{l}\text { Rahat and Sha- } \\
\text { pira (2015) }\end{array}$ \\
\hline
\end{tabular}




\begin{tabular}{|c|c|c|c|c|}
\hline & $\begin{array}{l}\text { 4.3. Decen- } \\
\text { tralization in } \\
\text { the definition } \\
\text { of the gover- } \\
\text { nment pro- } \\
\text { gram }\end{array}$ & $\begin{array}{l}\text { Is there a statutory } \\
\text { requirement for } \\
\text { the participation of } \\
\text { partisan state and } \\
\text { municipal agencies } \\
\text { in the preparation } \\
\text { of the government } \\
\text { program of the can- } \\
\text { didate for President } \\
\text { of the Republic and } \\
\text { municipal agencies, } \\
\text { in that of the can- } \\
\text { didate for govern- } \\
\text { ment? }\end{array}$ & $\begin{array}{l}\text { In a system of per- } \\
\text { sonified presiden- } \\
\text { tialism, the gover- } \\
\text { nment program for } \\
\text { the leadership of } \\
\text { the Executive is an } \\
\text { important docu- } \\
\text { ment for the party's } \\
\text { communication } \\
\text { with society and, } \\
\text { thus, it is relevant } \\
\text { for the democratic } \\
\text { character of the } \\
\text { party the decen- } \\
\text { tralization of the } \\
\text { discussion and the } \\
\text { formulation of the } \\
\text { program. }\end{array}$ & $\begin{array}{l}\text { Berge, Pogun- } \\
\text { tke, Obert and } \\
\text { Tipei (2013) }\end{array}$ \\
\hline & $\begin{array}{l}\text { 4.4. Inclusion } \\
\text { in the defi- } \\
\text { nition of the } \\
\text { government } \\
\text { program }\end{array}$ & $\begin{array}{l}\text { Is there statutory } \\
\text { provision for the } \\
\text { participation of affi- } \\
\text { liates in the elabora- } \\
\text { tion of the govern- } \\
\text { ment program? }\end{array}$ & $\begin{array}{l}\text { The participation of } \\
\text { affiliates in the ela- } \\
\text { boration of the pro- } \\
\text { gram represents a } \\
\text { democratic aspect } \\
\text { of the formulation } \\
\text { of the government } \\
\text { proposal. }\end{array}$ & $\begin{array}{l}\text { Rahat and Sha- } \\
\text { pira (2015) }\end{array}$ \\
\hline & $\begin{array}{l}\text { 4.5. Decision } \\
\text { on coalitions }\end{array}$ & $\begin{array}{l}\text { Is there statutory } \\
\text { provision for the } \\
\text { participation of } \\
\text { members in the } \\
\text { decision on the for- } \\
\text { mation of coalitions } \\
\text { in the three federal } \\
\text { spheres? }\end{array}$ & $\begin{array}{l}\text { Coalition-building } \\
\text { implies not only a } \\
\text { symbolic link with } \\
\text { one or more parties } \\
\text { with different pro- } \\
\text { grams, but also has } \\
\text { a significant impact } \\
\text { on the chances of } \\
\text { candidate affilia- } \\
\text { tes; thus, decision } \\
\text { making on coali- } \\
\text { tion-building is im- } \\
\text { portant and should } \\
\text { be done democra- } \\
\text { tically. }\end{array}$ & \\
\hline $\begin{array}{l}5 . \\
\text { Recruitment }\end{array}$ & $\begin{array}{l}\text { 5.1. Require- } \\
\text { ments for the } \\
\text { submission of } \\
\text { applications }\end{array}$ & $\begin{array}{l}\text { Is there provision in } \\
\text { the articles of asso- } \\
\text { ciation for all mem- } \\
\text { bers to be able to } \\
\text { present themselves } \\
\text { as candidates in the } \\
\text { agreements, in ad- } \\
\text { dition to the requi- } \\
\text { rement of financial } \\
\text { obligations? }\end{array}$ & $\begin{array}{l}\text { The requirement } \\
\text { for support from } \\
\text { a large number of } \\
\text { members for the } \\
\text { registration of can- } \\
\text { didates or slates } \\
\text { for the nomination } \\
\text { decreases the pos- } \\
\text { sibility of democra- } \\
\text { tic participation of } \\
\text { affiliates. }\end{array}$ & $\begin{array}{l}\text { Freid e n berg } \\
(2003) ; \quad \text { Ber- } \\
\text { ge, Poguntke, } \\
\text { Obert and Tipei } \\
(2013)\end{array}$ \\
\hline
\end{tabular}




\begin{tabular}{|c|c|c|c|}
\hline $\begin{array}{l}\text { 5.2. Participa- } \\
\text { tion of mino- } \\
\text { rities }\end{array}$ & $\begin{array}{l}\text { Does the party sta- } \\
\text { tute provide for } \\
\text { the participation of } \\
\text { minorities (women, } \\
\text { blacks, young peo- } \\
\text { ple and indigenous } \\
\text { people among the } \\
\text { candidates? }\end{array}$ & $\begin{array}{l}\text { The participation } \\
\text { of minorities on } \\
\text { the party list is an } \\
\text { essential element } \\
\text { for the democratic } \\
\text { characterisation of } \\
\text { a party. }\end{array}$ & $\begin{array}{l}\text { Berge, Pogun- } \\
\text { tke, Obert and } \\
\text { Tipei (2013); } \\
\text { Salgado (2015) }\end{array}$ \\
\hline $\begin{array}{l}\text { 5.3. How to } \\
\text { define appli- } \\
\text { cations }\end{array}$ & $\begin{array}{l}\text { Is there provision } \\
\text { in the articles of } \\
\text { association for the } \\
\text { equal participation } \\
\text { of members in the } \\
\text { definition of party } \\
\text { candidates? }\end{array}$ & $\begin{array}{l}\text { Equal voting in the } \\
\text { formation of the list } \\
\text { has a democratic } \\
\text { aspect because it } \\
\text { diminishes the in- } \\
\text { fluence of party lea- } \\
\text { ders and delegates } \\
\text { in the determina- } \\
\text { tion of candidates. }\end{array}$ & $\begin{array}{lr}\text { Freide } n \text { berg } \\
(2003) ; & \text { Gallo } \\
(2005) ; & \text { Rahat } \\
\text { and } & \text { Shapira } \\
(2015) & \end{array}$ \\
\hline $\begin{array}{l}\text { 5.4. Distribu- } \\
\text { tion of free } \\
\text { advertising } \\
\text { time }\end{array}$ & $\begin{array}{l}\text { Does the statute } \\
\text { provide for equal } \\
\text { distribution of free } \\
\text { advertising time } \\
\text { among candidates } \\
\text { for the same posi- } \\
\text { tion? }\end{array}$ & $\begin{array}{l}\text { Equality between } \\
\text { the affiliates on } \\
\text { the list, which is } \\
\text { a democratic re- } \\
\text { quirement, is only } \\
\text { characterised by } \\
\text { equal access to par- } \\
\text { ty resources for the } \\
\text { electoral campaign. }\end{array}$ & \\
\hline $\begin{array}{l}\text { 5.5. Distribu- } \\
\text { tion of resour- } \\
\text { ces }\end{array}$ & $\begin{array}{l}\text { Do the Staff Regu- } \\
\text { lations provide for } \\
\text { equal distribution } \\
\text { of public resources } \\
\text { between candida- } \\
\text { tes running for the } \\
\text { same position? }\end{array}$ & $\begin{array}{l}\text { Equality between } \\
\text { the affiliates on } \\
\text { the list, which is } \\
\text { a democratic re- } \\
\text { quirement, can be } \\
\text { characterised by } \\
\text { equal access to par- } \\
\text { ty resources for the } \\
\text { electoral campaign. }\end{array}$ & \\
\hline
\end{tabular}

\section{THE DEGREE OF INTERNAL DEMOCRACY OF BRAZILIAN POLITI- CAL PARTIES}

The model was applied to the analysis of the statutes of each of the 35 parties registered at the Superior Electoral Court, with "yes" (=1) or "no" (=0) answers given to each of the questions/variables. Thus, it was possible to achieve the intra-party democracy index (IDI) for each of the associations, in addition to evaluating the statutes in each of the dimensions and indicators.

The IDI is not the average between the indexes of each of the two dimensions. It was calculated taking into account that all five indicators, divided into the two dimensions, have equal weight for the formation of the index and, therefore, the sum of the indicator values should be divided by five so that the index also has a value between 0 and 1. 


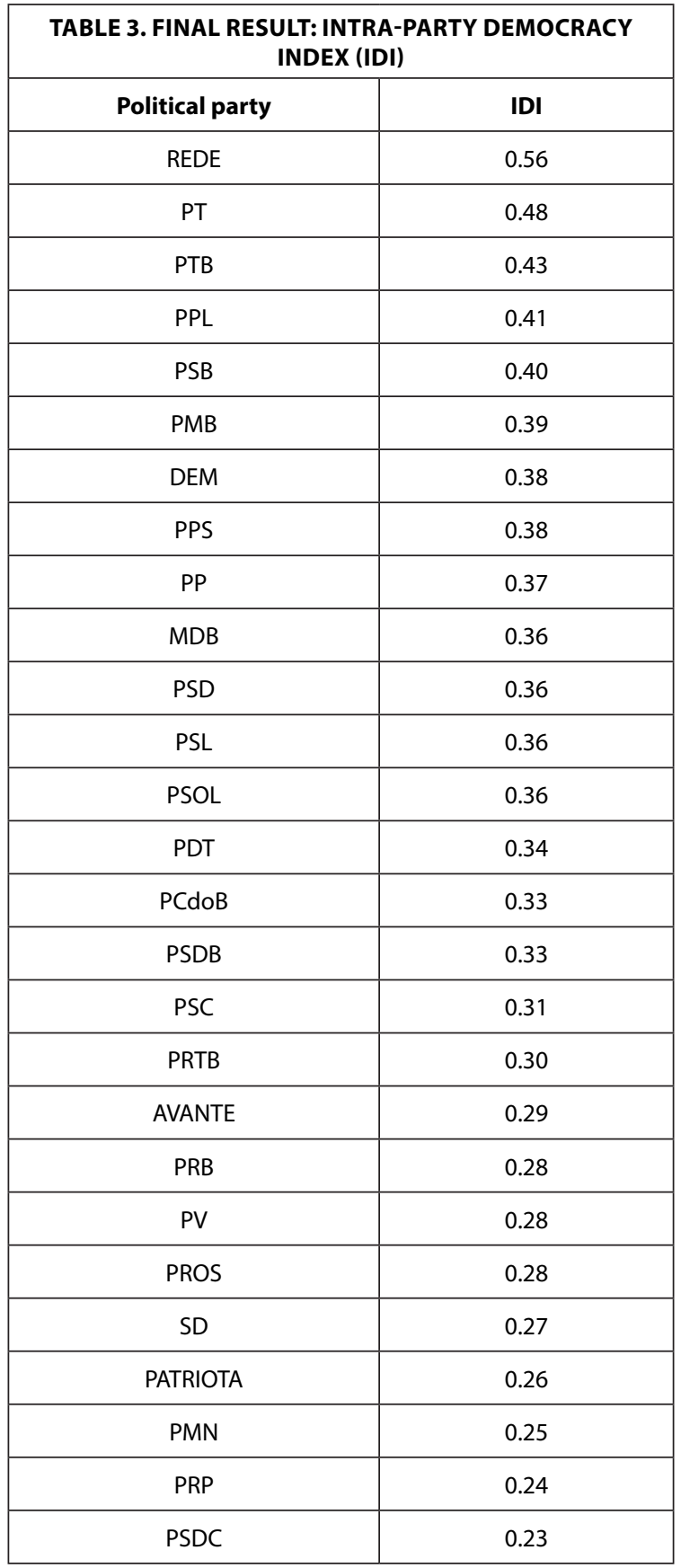




\begin{tabular}{|c|c|}
\hline PODE & 0.23 \\
\hline PCB & 0.21 \\
\hline PR & 0.21 \\
\hline PTC & 0.19 \\
\hline NOVO & 0.17 \\
\hline PSTU & 0.15 \\
\hline PHS & 0.12 \\
\hline PCO & 0.10 \\
\hline
\end{tabular}

Source: the author

REDE Sustentabilidade (REDE) was the only party that presented an IDI above 0.50. Only four other parties scored 4.0 points or more and ten parties fell below 0.25 . The strong performance of REDE can be largely attributed to the great decentralization in the decision-making process, since it was in this variable that the party obtained more points.

Three indicators form the organizational structure dimension: composition of the partisan bodies, the conflict resolution system, and the relationship between the partisan bodies. In this dimension, REDE still performed the best, but with the same index attributed to Partido dos Trabalhadores (PT) and very close to that shown by Partido Trabalhista Brasileiro (PTB).

Taking into account each indicator individually, other parties emerge with higher indexes of internal democracy. When considering the composition of the partisan bodies alone, the Partido Popular Socialista (PPS) has the highest index (0.86), followed by REDE, PT, Partido Progressista (PP), and the Partido da Social Democracia Brasileira (PSDB), all with 0.72 .

PTB has the highest index for the conflict resolution system (0.77) and eight parties have a 0.66 index for this indicator: REDE, PT, Partido Pátria Livre (PPL), Partido da Mulher Brasileira (PMB), Partido Democrático Trabalhista (PDT), Partido Comunista do Brasil (PCdoB), Partido Renovador Trabalhista Brasileiro (PRTB), and Partido Republicano Progressista (PRP). The Partido da Classe Operária (PCO) did not respond positively to any of the questions regarding this indicator and the second worst performance is that of PSDB, with only one positive response.

Finally, considering the relationship between the partisan bodies, none of the parties answered affirmatively to more than three questions. Eleven parties scored 0.60 (REDE, PT, PTB, Partido Socialista Brasileiro (PSB), PMB, PPS, Movimento Democrático Brasileiro (MDB), Partido Social Democrático (PSD), PSDB, Partido Social Cristão (PSC) 
and Partido Verde (PV)). The Partido Comunista Brasileiro (PCB), the Partido Trabalhista Cristão (PTC), the Partido Novo (NOVO) and the Partido Socialista dos Trabalhadores Unificado (PSTU) did not achieve any positive response in the indicator.

\section{TABLE 4. VALUES OF THE “ORGANIZATIONAL STRUCTURE” DIMENSION IN THE THREE INDI- CATORS MEASURED}

\begin{tabular}{|c|c|c|c|c|}
\hline $\begin{array}{l}\text { Political } \\
\text { parties }\end{array}$ & $\begin{array}{l}\text { Composition } \\
\text { of the partisan } \\
\text { bodies (A) }\end{array}$ & $\begin{array}{l}\text { Conflict resolu- } \\
\text { tion system (B) }\end{array}$ & $\begin{array}{l}\text { Relationship } \\
\text { between the } \\
\text { partisan bodies } \\
\text { (C) }\end{array}$ & $\begin{array}{l}\text { Organization- } \\
\text { al structure } \\
(A+B+C / 3)\end{array}$ \\
\hline REDE & 0.72 & 0.66 & 0.60 & 0.66 \\
\hline PT & 0.72 & 0.66 & 0.60 & 0.66 \\
\hline PTB & 0.57 & 0.77 & 0.60 & 0.65 \\
\hline PPL & 0.57 & 0.66 & 0.40 & 0.54 \\
\hline PSB & 0.57 & 0.22 & 0.60 & 0.46 \\
\hline PMB & 0.29 & 0.66 & 0.60 & 0.52 \\
\hline DEM & 0.57 & 0.55 & 0.20 & 0.44 \\
\hline PPS & 0.86 & 0.22 & 0.60 & 0.56 \\
\hline PP & 0.72 & 0.55 & 0.40 & 0.56 \\
\hline MDB & 0.57 & 0.44 & 0.60 & 0.54 \\
\hline PSD & 0.57 & 0.44 & 0.60 & 0.54 \\
\hline PSL & 0.57 & 0.44 & 0.40 & 0.47 \\
\hline PSOL & 0.57 & 0.44 & 0.40 & 0.47 \\
\hline PDT & 0.43 & 0.66 & 0.20 & 0.43 \\
\hline PCdoB & 0.57 & 0.66 & 0.40 & 0.54 \\
\hline PSDB & 0.72 & 0.11 & 0.60 & 0.48 \\
\hline PSC & 0.43 & 0.33 & 0.60 & 0.45 \\
\hline PRTB & 0.43 & 0.66 & 0.40 & 0.50 \\
\hline AVANTE & 0.29 & 0.55 & 0.40 & 0.41 \\
\hline PRB & 0.57 & 0.44 & 0.40 & 0.47 \\
\hline PV & 0.57 & 0.22 & 0.60 & 0.46 \\
\hline PROS & 0.14 & 0.44 & 0.40 & 0.33 \\
\hline SD & 0.29 & 0.44 & 0.40 & 0.38 \\
\hline
\end{tabular}




\begin{tabular}{|c|l|l|l|l|}
\hline PATRIOTA & 0.29 & 0.22 & 0.40 & 0.30 \\
\hline PMN & 0.43 & 0.22 & 0.40 & 0.35 \\
\hline PRP & 0.14 & 0.66 & 0.40 & 0.40 \\
\hline PSDC & 0.43 & 0.33 & 0.20 & 0.32 \\
\hline PODE & 0.29 & 0.44 & 0.20 & 0.31 \\
\hline PCB & 0.43 & 0.44 & 0.00 & 0.29 \\
\hline PR & 0.29 & 0.55 & 0.20 & 0.35 \\
\hline PTC & 0.29 & 0.44 & 0.00 & 0.24 \\
\hline NOVO & 0.43 & 0.44 & 0.00 & 0.29 \\
\hline PHS & 0.00 & 0.22 & 0.40 & 0.21 \\
\hline PSTU & 0.43 & 0.33 & 0.00 & 0.25 \\
\hline PCO & 0.29 & 0.00 & 0.20 & 0.16 \\
\hline
\end{tabular}

Source: the author. The table is organized by IDI.

There are smaller differences between the parties regarding the decision-making process dimension, primarily because it is made up of fewer variables than the first dimension. It is in this dimension that REDE excels in relation to the other parties, but only in the definition of the program: while it stands out with 0.60 in this indicator, only three parties score 0.40 (PT, PSB and Partido Republicano da Ordem Social (PROS)). Ten answered affirmatively to only one question (PPL, PMB, Democratas (DEM), PP, Partido Social Liberal (PSL), Partido Socialismo com Liberdade (PSOL), PDT, PSDB, Patriota and the Partido Humanista da Solidariedade (PHS)), and twenty-one parties did not record a positive response in any variable regarding the definition of the program.

The indicator relating to the recruitment of candidates and the distribution of resources is the one that received the fewest positive responses. Of the five variables, DEM answered affirmatively to two, 20 parties fulfilled only one of the requirements of internal democracy, and 14, none. 


\begin{tabular}{|c|c|c|c|}
\hline \multicolumn{4}{|c|}{$\begin{array}{c}\text { TABLE 5. VALUES OF THE “DECISION-MAKING PROCESS” DIMENSION IN THE } \\
\text { TWO INDICATORS MEASURED }\end{array}$} \\
\hline Political parties & $\begin{array}{l}\text { Definition of the pro- } \\
\text { gram } \\
\text { (A) }\end{array}$ & $\begin{array}{c}\text { Recruitment } \\
\text { (B) }\end{array}$ & $\begin{array}{c}\text { Decision-making pro- } \\
\text { cess } \\
(\mathrm{A}+\mathrm{B} / 2)\end{array}$ \\
\hline REDE & 0.6 & 0.2 & 0.4 \\
\hline PT & 0.4 & 0.0 & 0.2 \\
\hline PTB & 0.0 & 0.2 & 0.1 \\
\hline PPL & 0.2 & 0.2 & 0.2 \\
\hline PSB & 0.4 & 0.2 & 0.3 \\
\hline PMB & 0.2 & 0.2 & 0.2 \\
\hline DEM & 0.2 & 0.4 & 0.3 \\
\hline PPS & 0.0 & 0.2 & 0.1 \\
\hline PP & 0.2 & 0.0 & 0.1 \\
\hline MDB & 0.0 & 0.2 & 0.1 \\
\hline PSD & 0.0 & 0.2 & 0.1 \\
\hline PSL & 0.2 & 0.2 & 0.2 \\
\hline PSOL & 0.2 & 0.2 & 0.2 \\
\hline PDT & 0.2 & 0.2 & 0.2 \\
\hline PCdoB & 0.0 & 0.0 & 0.0 \\
\hline PSDB & 0.2 & 0.0 & 0.1 \\
\hline PSC & 0.0 & 0.2 & 0.1 \\
\hline PRTB & 0.0 & 0.0 & 0.0 \\
\hline AVANTE & 0.0 & 0.2 & 0.1 \\
\hline PRB & 0.0 & 0.0 & 0.0 \\
\hline PV & 0.0 & 0.0 & 0.0 \\
\hline PROS & 0.4 & 0.0 & 0.2 \\
\hline SD & 0.0 & 0.2 & 0.1 \\
\hline PATRIOTA & 0.2 & 0.2 & 0.2 \\
\hline PMN & 0.0 & 0.2 & 0.1 \\
\hline PRP & 0.0 & 0.0 & 0.0 \\
\hline
\end{tabular}




\begin{tabular}{|c|c|c|c|}
\hline PSDC & 0.0 & 0.2 & 0.1 \\
\hline PODE & 0.0 & 0.2 & 0.1 \\
\hline PCB & 0.0 & 0.2 & 0.1 \\
\hline PR & 0.0 & 0.0 & 0.0 \\
\hline PTC & 0.0 & 0.2 & 0.1 \\
\hline NOVO & 0.0 & 0.0 & 0.0 \\
\hline PHS & 0.2 & 0.0 & 0.0 \\
\hline PSTU & 0.0 & 0.0 & 0.0 \\
\hline PCO & 0.0 & 0.0 & 0.0 \\
\hline
\end{tabular}

Source: the author. The table is organized by IDI.

It is still worth mentioning some characteristics observed through the application of the proposed model that may demonstrate the deficiencies of the Brazilian system with regard to the proposed requirements for intra-party democracy. Of the 35 registered parties, 16 adopt the proportional system for the composition of their bodies and nine reserve vacancies in the directories for minorities, but only six require the bodies and leaders to be actively accountable to their affiliates (PPS, PCdoB, PMN, PPL, REDE and NOVO) and none prohibit the re-election of leaders.

Due process of law and broad defence, which are constitutional principles, are not observed in cases of conflicts between partisan bodies in 20 statutes. When it comes to disciplinary protocols for members, two statutes do not expressly indicate the applicable faults and punishments (PHS and PCO), 16 do not guarantee at least three days for the defence of the affiliate, and in two cases there is no possibility of appeals against the decision (PSDB and PCO). Fourteen parties' statutes do not guarantee funding from the political funding to state bodies, only one forbids the existence of provisional commissions for more than six months (PPS), and none prohibit the dissolution of state directories by national agencies.

In seven statutes there is the possibility of participation of state agencies in the elaboration and reform of party programs (PSDB, PDT, PSB, PSL, PROS, PATRIOTA and $P P L)$ and six allow the participation of affiliates (DEM, PSB, PSOL, PROS, PMB and REDE). Regarding the elaboration of the national government plan, two parties deal with the participation of affiliates (PT and REDE) and only one party refers to the participation of subnational agencies (PP). In relation to the decision on coalitions, the participation of affiliates is stipulated in only two statutes (PT and REDE).

Finally, recruitment appears to be the most deficient area in terms of democratic requirements. Of the 35 statutes, 20 have no other requirements than ordinary financial 
obligations for affiliates to be able to be indicated as candidates by the party and only one guarantees minority participation in the nomination (PDT). Also, only one provides for equal distribution of free advertising media time among candidates running for the same position (DEM) and none guarantees equality among affiliates in the definition of candidates or equal distribution of public resources allocated to the parties.

\section{CONCLUSION: THE LOW DEGREE OF DEMOCRACY IN BRAZI- LIAN PARTIES}

The results of applying the model for measuring the intra-party democracy concur with the original hypothesis, which was that parties would tend towards more oligarchic forms of organization. By reading parties' statutes, it is possible to observe that the majority of Brazilian political parties do not ascribe to democratic mechanisms for their internal organization and decision-making processes. Although the lack of permeability of affiliates' opinions in recruiting candidates is more evident, the index of the relationship between the partisan bodies is also low. According to the statutes themselves, there is a concentration of power and resources in the central directories, which is quite a serious issue in a peculiar federation that does not allow the organization of local parties.

In a (supposedly) democratic State, it cannot be conceivable that partisan associations, which maintain a monopoly on presenting alternatives to the electorate and receive both substantial public resources, and indirect funding through free access to mass media, can function without respecting minimum levels of equality, participation, transparency, and control. The 1988 Constitution guarantees political parties autonomy for their organization and functioning, but this does not represent an authorization to deny the constitutional principles that structure the Brazilian State and society more broadly.

The ideal scenario would be a democratization of the parties demanded by their affiliates. However - and here the academic background of the researcher clearly emerges - Law can serve to promote democratization. The elaboration and imposition of legal rules to guarantee internal democracy, while recognizing the difficulty of reaching a consensus on what the legislative requirements for the configuration of a democratic standard for the parties would be, as well as the fundamental rights of the affiliates, does not correspond to a setback in the face of partisan autonomy, but rather to an advance in the development of the constitutionally promised democracy.

A parallel utility for the analysis reported herein would be to consider parties' scores in each dimension to determine the distribution of direct and indirect public resources. This would privilege more democratic parties, and help to replace the current model of favouring parties based on their performance in the previous election. Taking 
into account the degree of internal democracy when allocating party funding or the special fund for campaign financing, could foster the adoption of more participatory and democratic ways of party organization and functioning.

An approach such as this would necessitate concrete verification of parties' practices and should not rely solely on parties' statutes. Finally, this analysis of intra-party democracy is a useful starting point for future research. One possibility is to examine whether parties that claim to be more pluralist in their statutes demonstrate more diversity in the composition of their nominees and bodies. Another is to compare the parties' practices as envisaged through their statutes with the speeches of their leaders and other members on the topic of democracy and its scope.

\section{REFERENCES}

AGUIAR, Joaquim. Democracia pluralista, partidos políticos e relação de representação. Análise Social: Revista do Instituto de Ciências Sociais, v. 24, n. 100, pp. 59-76 1988.

ALENCAR, José de. O sistema representativo. In: SANTOS, Wanderley Guilherme dos. Dois escritos democráticos de José de Alencar. Rio de Janeiro: Editora da UFRJ, 1991 [1868/1874].

ALMAGRO CASTRO, David. Democracia y financiación de los partidos políticos en España. Revista Direito GV, v. 10, n. 2, pp. 535-558, jul./dez. 2014.

ARAGON, Fernando M. Candidate Nomination Procedures and Political Selection: Evidence from Latin American Parties (January 2009). LSE STICERD Research Paper No. EOPP003. https://ssrn. com/abstract $=1546897$.

ARANA, Xabier; HOGG, Alison H. Drug Policy and the Ultima Ratio in a Social and Democratic State, Spain (January 15, 2013). Oñati Socio-Legal Series, Vol. 3, No. 1, 2013. https://ssrn.com/ abstract $=2200886$

ARENAS CATALÁN, Eduardo Salvador. Democracy as a Legitimizing Principle for the Current Chilean Constitution: External and Internal Perspectives (August 11, 2006). https://ssrn.com/ abstract $=2019996$.

BARREIRO NETO, Jaime. Os partidos políticos como elementos essenciais à democracia moderna. Semestre eleitoral, v. 12, n. 1/2, pp. 9-44, jan./dez. 2008.

BERGE, Benjamin von dem; POGUNTKE, Thomas; OBERT, Peter; TIPEI, Diana. Measuring Intra-Party Democracy: A Guide for the Content Analysis of Party Statutes with Examples from Hungary, Slovakia and Romania. SpringerBriefs in Political Science, 2013.

BICUDO, Hélio. A Democracia nos partidos políticos. O Estado de São Paulo, n. 36279, 15 fev. 1993. caderno Economia \& Negócios / coluna Espaço Aberto, p. 2. 
BORJA, Célio. Os Partidos políticos e a democracia brasileira. Segurança \& desenvolvimento, v. 21, n. 149, pp. 111-117, 1972.

CAMBI, Eduardo; OLIVEIRA, Priscila Sutil de. Crise da democracia representativa e revitalização dos partidos políticos no Brasil. Revista dos Tribunais, v. 103, n. 949, pp. 39-67, nov. 2014.

CAMPOS NETO, Raymundo. A democracia interna nos partidos políticos brasileiros. Belo Horizonte: Editora D'Plácido, 2017.

CARVALHO, Carlos Eduardo Vieira de. Os Partidos políticos e a democracia. Revista de ciência política / Instituto de Direito Público e Ciência Política, v. 33, n. 2, pp. 11-25, fev./abr. 1990.

CENEVIVA, Walter. Mudanças na lei dos partidos políticos garantirão a democracia. Folha de $\mathbf{S}$. Paulo, n. 23384, 11 abr. 1993. caderno Cotidiano / coluna Letras Jurídicas, pp. 4-2.

CERQUEIRA, Marcelo. Partidos políticos: democracia interna e financiamento de campanha: a reforma política e o jardineiro infiel. Revista da Academia Brasileira de Direito Constitucional, $\mathrm{v}$. 10 B, pp. 343-364, 2006.

COSTA, Alcir Molina de. Democracia e partidos políticos. Revista de Direito da Defensoria Pública, v. 10, n. 13, pp. 219-221, 1998.

CRUZ, llídio. O papel dos partidos políticos numa democracia multipartidária. Paraná Eleitoral, n. 40, p. 63-68, abr./jun. 2001.

DIRCEU, José. A democracia e os partidos políticos. O Estado de São Paulo, n. 36270, 6 fev. 1993. caderno Economia \& Negócios / coluna Espaço Aberto, p. 2.

FERREIRA FILHO, Manoel Gonçalves. Os partidos políticos nas Constituições democráticas. Belo Horizonte: Revista Brasileira de Estudos Políticos, 1966.

FORTIN-RITTBERGER, Jessica and RITTBERGER, Berthold. Nominating Women for EP Elections: Exploring the Role of Political Parties' Recruitment Procedures (2014). APSA 2014 Annual Meeting Paper. https://ssrn.com/abstract=2455671.

FREIDENBERG, Flavia. Selección de candidatos y democracia interna en los partidos de América Latina. Lima: Asociación Civil Transparencia, 2003.

GALLO, Adriana. La democracia interna en el ámbito partidario. Un estudio comparado en partidos latinoamericanos. Reflexión política, pp. 26-39, 2005.

GARCÍA ROCA, F. Javier; MURILLO DE LA CUEVA, Pablo Lucas. Democracia interna y control de los partidos politicos - cronica del encuentro italo-español de octubre de 1983. Revista de estudios políticos, n. 42, pp. 239-268, nov./dic. 1984.

GARCÍA-PELAYO, Manuel. El Estado de partidos. Madrid: Alianza Editorial, 1996 [1986].

GIL-LAFUENTE, Jaime; ROJAS-MORA, Julio; ACUNA-AGOST, Rodrigo. Y Ahora con Quién Tenemos Que Pactar? Modelo Matemático Para la Obtención de Coaliciones de Gobierno en una 
Democracia Parlamentaria (March 23, 2009). Proceedings of the XXIII Anual Congress of the AEDEM, 2009. https://ssrn.com/abstract=1657897.

GRESTA, Roberta Maia. Introdução aos fundamentos da processualidade democrática. Rio de Janeiro: Lumen Juris, 2014.

GRIMM, Dietter. Os partidos políticos como pressupostos ou ameaças para a democracia. Revista de direito constitucional e ciência política, v. 4, n. 6, pp. 85-100, jan./jun. 1988.

HILLMAN, Richard S.; D'AGOSTINO, Thomas J. Partidos políticos, opinião pública e o futuro da democracia na Venezuela. Opinião pública, v. 6, n. 1, pp. 55-76, abr. 2000.

JUCA, Francisco Pedro. Democracia e partidos políticos. Revista do Centro de Ciências Jurídicas da Universidade Federal do Pará, v. 1, n. 1, pp. 109-139, 1988.

KLEIN, Antonio Carlos. Os partidos políticos e o paradoxo da democracia representativa. Revista Latino-Americana de Estudos Constitucionais, n. 16, pp. 369-390, dez. 2014.

LALANDER, Rickard. Venezuela 2010-2011: Polarización Y Radicalización Del Proyecto Socialista (September 2, 2012). Revista de Ciencia Política Vol. 32, No.1, 2012. https://ssrn.com/ abstract $=2349067$.

LOMBARDI, Giorgi. Corrientes y democracia interna de los partidos políticos. Revista de estudios políticos, n. 27, pp. 7-28, mayo/jun. 1982.

MARANHÃO, Jarbas. Partidos políticos e democracia. Revista de Informação Legislativa, v. 51, n. 201, pp. 245-249, jan./mar. 2014.

MARTÍN REYES, Javier. De jueces, militantes y dirigencias partidistas: un panorama cuantitativo del control jurisdiccional de los conflictos intrapartidistas en México - 1996-2006. Veredas, Xochimilco, v. 25, p. 177-208, 2012. https://ssrn.com/abstract=2341384.

MARTÍN REYES, Javier. El tribunal de los militantes: el control judicial de los conflictos intrapartidistas en México. América Latina Hoy, Salamanca, v. 62, p. 131-153, 2012. https://ssrn.com/ abstract $=2341351$.

MARTÍN REYES, Javier. Un garantismo en tension: la primera integración del TEPJF y el control jurisdiccional de la vida interna de los partidos políticos. Justicia Electoral, vol. 1, n. 10, p. 223-266, 2012. https://ssrn.com/abstract=2341379.

MEZZAROBA, Orides. A democracia, os partidos políticos e o Estado. Seqüência: Revista do Curso de Pós-graduação em Direito da UFSC, v. 22, n. 43, p. 29-44, dez. 2001.

MICHELS, Robert. Los partidos políticos. Un estudio sociológico de las tendencias oligárquicas de la democracia moderna. 2 vols. Buenos Aires: Amorrortu, 2008 [1962].

MILL, John Stuart. Considerações sobre o governo representativo. Brasília: Editora Universidade de Brasília, 1981 [1861]. 
MORAES, Filomeno; LIMA, Martonio Mont'Alverne Barreto. Partidos políticos, eleições e a justiça eleitoral na construção da democracia no Brasil. Revista Latino-Americana de Estudos Constitucionais, n. 3, pp. 291-313, jan./jun. 2004.

NUNES, Georgia Ferreira Martins. A (i)legitimidade representativa no/do sistema eleitoral proporcional no Brasil: a (des)necessidade de uma reforma política. Dissertação. Mestrado em Direito. Universidade do Vale do Rio dos Sinos, 2015.

ORTEGA, Marvin. Democracia y partidos politicos en Nicaragua. Pensamiento iberoamericano: revista de economia política, n. 14, pp. 231-237, jul./dic. 1988.

OSTROGORSKI, Moisei. La democracia y los partidos políticos. Madrid: Editorial Trotta, 2008 [1912].

POGUNTKE, Thomas; SCARROW, Susan E.; WEBB, Paul D. Party rules, party resources and the politics of parliamentary democracies: How parties organize in the 21st century. Party Politics, 2016.

RAHAT, Gideon; SHAPIRA, Assaf. An Intra-Party Democracy Index: Theory, Design and a Demonstration. Parliamentary Affairs, p. 1-27, 2016.

REALE, Miguel. Os partidos políticos e a democracia no ocidente e no Brasil. Segurança \& desenvolvimento, v. 30, n. 186, pp. 47-56, 1981.

RODRIGUEZ ALVAREZ, Maria Pilar. El principio de democracia en la estructura y funcionamiento de los partidos políticos. Revista de la Facultad de Derecho de la Universidad de Madrid, n. 81, pp. 291-300, 1993.

SALGADO, Eneida Desiree; PÉREZ HUALDE, Alejandro. A democracia interna dos partidos políticos como premissa da autenticidade democrática. A \& C: Revista de Direito Administrativo \& Constitucional, v. 15, n. 60, pp. 63-83, abr./jun. 2015.

SALGADO, Eneida Desiree. Princípios constitucionais eleitorais. Belo Horizonte: Fórum, 2015.

SARLET, Ingo Wolfgang. A eficácia dos direitos fundamentais. Uma teoria geral dos direitos fundamentais na perspectiva constitucional. Porto Alegre: Livraria do Advogado, 2015.

SENA, Jorge F. Malem. Financiación de partidos políticos, democracia y corrupción. Revista dos Mestrandos em Direito Econômico da UFBA, n. 6, pp. 377-417, jan./dez. 1998.

STOKES, Susan C. Son los partidos políticos el problema de la democracia en America Latina? Política y gobierno, v. 5, n. 1, pp. 13-46, jan./jun. 1998.

TEIXEIRA, José Eleares Marques. Democracia nos partidos políticos. Boletim Científico da Escola Superior do Ministério Público da União, v. 2, n. 8, pp. 83-98, jul./set. 2003.

TEODORO, Luiz Cláudio de Almeida. Partidos políticos e democracia no Brasil. Caderno de filosofia e ciências humanas, v. 6, n. 10, pp. 144-150, abr. 1998.

WEIL, S. Sobre a supressão dos partidos políticos. São Paulo: lluminuras, 2018 [1940]. 
YURTSEVER, Leyla Viga. A crise da democracia representativa e os partidos políticos no Brasil. L \& C: Revista de Administração Pública e Política, v. 17, n. 194, pp. 10-19, ago. 2014.

Statutes of political parties registered with the Supreme Electoral Court, accessed on August 17, 2018.

MDB: http://www.justicaeleitoral.jus.br/arquivos/tse-estatuto-partido-movimento-democratico-brasileiro

PT: http://www.justicaeleitoral.jus.br/arquivos/tse-estatuto-do-partido-pt-de-3-6-2017-aprovado-em-17-10-2017

PSDB: $\quad$ http://www.justicaeleitoral.jus.br/arquivos/tse-estatuto-psdb-de-9-12-2015-deferido-em-29-3-2016

PP: $\quad$ http://www.justicaeleitoral.jus.br/arquivos/tse-estatuto-partido-de-5-12-2017-aprovado-em-11-9-2018

PDT: $\quad$ http://www.justicaeleitoral.jus.br/arquivos/tse-estatuto-do-partido-pdt-aprovado-em-26-5-2015

PTB: http://www.justicaeleitoral.jus.br/arquivos/tse-estatuto-ptb-de-26-11-2016-aprovado-no-tse-em-29-6-2017

DEM: http://www.justicaeleitoral.jus.br/arquivos/estatuto-do-partido-de-12-12-2007-resolucao-tse-no.2008

PR: http://www.justicaeleitoral.jus.br/arquivos/tse-estatuto-do-partido-pr-de-2-5-2015-aprovado-em-13-8-2015

PSB: $\quad$ http://www.justicaeleitoral.jus.br/arquivos/tse-estatuto-psb-de-02-12-2011-deferido-em-28-5-2013

PPS: $\quad$ http://www.justicaeleitoral.jus.br/arquivos/tse-estatuto-do-partido-pps-de-16-12-2013-aprovado-em-11-6-2014

PSC: http://www.justicaeleitoral.jus.br/arquivos/tse-estatuto-do-partido-psc-de-7-6-2017-aprovado-em-15-5-2018-1542125746040

PRB: http://www.justicaeleitoral.jus.br/arquivos/tse-estatuto-do-partido-prb-de-24-2-2014-aprovado-em-5-8-2014

PCdoB: http://www.justicaeleitoral.jus.br/arquivos/tse-estatuto-do-partido-comunista-do-brasil.2011

PV: http://www.justicaeleitoral.jus.br/arquivos/tse-estatuto-do-partido-verde-pv-de-26-11-2011

PSD: $\quad$ http://www.justicaeleitoral.jus.br/arquivos/tse-estatuto-do-psd-deferido-em-20-fevereiro-2018 
PRP: $\quad$ http://www.justicaeleitoral.jus.br/arquivos/tse-estatuto-do-partido-prpde-16-10-2017aprovada-em-26-6-2018

PSL: http://www.tse.jus.br/arquivos/tse-estatuto-psl-de-21-12-2011-deferido-em-9-5-2013

PMN:

http://www.justicaeleitoral.jus.br/arquivos/estatuto-de-23-7-2016-aprovado-

em-30-3-2017

PHS: $\quad$ http://www.justicaeleitoral.jus.br/arquivos/tse-estatuto-do-partido-phs-aprovado-em-10-2-2015

SD: http://www.justicaeleitoral.jus.br/arquivos/tse-estatuto-solidariedade-de-17-2-2016-aprovado-em-28-6-2018

PTC: $\quad$ http://www.justicaeleitoral.jus.br/arquivos/tse-estatuto-do-partido-ptc-de-20-2-2017aprovado-tse-em-16-5-2017-formato-pdf

PSDC: $\quad$ http://www.justicaeleitoral.jus.br/arquivos/tse-estatuto-psdc-de-27-6-2017-deferidoem-17-5-2018

AVANTE: $\quad$ http://www.justicaeleitoral.jus.br/arquivos/tse-estatuto-do-avante-de-25-4-2017aprovado-em-12-9-2017

PODE: http://www.justicaeleitoral.jus.br/arquivos/estatuto-podemos-de-19-2-2016-aprovadoem-16-5-2017

PSOL: $\quad$ http://www.justicaeleitoral.jus.br/arquivos/estatuto-do-partido-socialismo-e-liberdade-de-1-4.2010

PRTB: http://www.justicaeleitoral.jus.br/arquivos/tse-estatuto-prtb-aprovado-em-25-11-2017deferido-tse-em-28-06-2018-1534199020704

PROS: $\quad$ http://www.justicaeleitoral.jus.br/arquivos/tse-estatuto-do-partido-pros-aprovado-em-21-5-2015

PATRIOTA: $\quad$ http://www.justicaeleitoral.jus.br/arquivos/tse-estatuto-do-partido-patriotade-26-8-2017-aprovado-em-26-4-2018

PMB: $\quad$ http://www.justicaeleitoral.jus.br/arquivos/tse-estatuto-pmb-de-9-10-2015-deferidoem-19-4-2016

PPL: $\quad$ http://www.justicaeleitoral.jus.br/arquivos/tse-estatuto-ppl-de-1-12-2013-deferidoem-25-5-2017

REDE: http://www.justicaeleitoral.jus.br/arquivos/tse-resolucao-do-partido-rede-sustentabilidade-aprovado-em-1-2-2017 
NOVO: $\quad$ http://www.justicaeleitoral.jus.br/arquivos/tse-estatuto-do-partido-novo-aprovado-em-26-04-2018

PSTU: http://www.justicaeleitoral.jus.br/arquivos/tse-estatuto-do-pstu-aprovado-em-11-9-2014

PCB: http://www.justicaeleitoral.jus.br/arquivos/tse-estatuto-do-partido-de-25-6-2017-aprovado-em-21-8-2018

PCO: $\quad$ http://www.justicaeleitoral.jus.br/arquivos/estatuto-do-partido-da-causa-operaria-de-9-12.1995 